\title{
Priority Directions of Ensuring Strategic Competitiveness and Sustainability of Industrial Enterprises
}

\author{
Tatiana Arkhipova ${ }^{1, *}$, and Margarita Afonasova ${ }^{1}$ \\ ${ }^{1}$ Tomsk State University of Control Systems and Radioelectronics, 634050, Lenina prospekt, 40, Tomsk, Russian Federation
}

\begin{abstract}
The paper presents the directions of sustainability and competitiveness improvement of industrial enterprises through the use of project management tools. Special attention is given to consideration of the prospects of application of project management methods at the enterprises of the aviation and rocket and space industry. Problems that enterprises face when implementing the project management tools are identified in terms of the analysis. Advantages of implementing the tools of project management at the enterprises of the aviation and rocket and space industry are determined. The paper shows that the Russian rocket and space industry loses competitive strength in the global market for space technologies and space services. This is due to a trend towards stagnation with respect to industrial enterprises. All of these in turn lead to an obstacle to fostering of enterprises based on innovation.
\end{abstract}

High-technology industrial facilities, which are able to meet competition, are the key to economic growth and social development. However, business and investment climate for conducting high-technology business in Russia is challenging.

The urgency of the problem of overcoming adverse economic trends is that a need for creating conditions necessary for economic growth as well as for encouraging the development of domestic production against the backdrop of adverse external factors and stagnation tendencies exists. The purpose of the study is to justify the directions of competitiveness and sustainability improvement of industrial enterprises based on the notion of economic growth, which implies priority innovation development of the industry through the use of project management methods and tools. This requires effective institutional and regulatory measures aimed at creating conditions for pulling industrial enterprises out of stagnation and putting them on a path of stable growth.

Currently, the Russian economy is characterized by fluctuating trends, slowdown, and the lack of positive structural changes. Despite the fact that a number of efforts aimed at improving the business environment, stimulating investment activity, and support for small and medium entrepreneurship are made by the government, the general economic environment in Russia remains unfavorable and non-competitive compared with other industrialized countries. According to the experts of RF Chamber of Commerce, tax issues, as well as monetary policy, are the most urgent for the Russian business. Economic growth rates do not correspond to tax rates, and a bank sector purge conducted by the Central Bank has led to market monopolization, increased costs of banking services, and a decline in lending of industrial enterprises.

The Central Bank policy results in a hollowing-out of the national banking system. Licenses of $43 \%$ of credit organizations have been revoked by the Central Bank over the period of 4.5 years of the new administration operation. There is a negative tendency to reducing the number of bank branches in the regions. At the present day, only 33 thousand bank offices account for 150 thousand population centers. There is no regional bank in 14 constituent territories of the Russian Federation, and there is only one bank left in 17 RF regions. The Central Bank key rate and deposit rate, that is, $7.25 \%$, exceed the inflation by two times; interbank lending is virtually non-existent [1].

In 2017, tax revenues for the treasure increased by $32 \%$; however, the growth of payment arrears of enterprises is noticed. Over the past 5 years, the number of bankrupt enterprises reached $30 \%$. Increase in the cost of energy resources and transportation, excessive bureaucratization of workflow, and a shortage of specialists in technical fields impede the growth of domestic production. At the same time, the manufacturing sector demonstrates a weak growth rate, which is close to the zero. Among 14 types of activities of the manufacturing sector, there is a significant growth only in chemical production, coke industry, and oil production in 2017 compared to 2013 [2].

However, there are some positive changes in the industrial policy. In recent years, a number of subsidy programmes of product promotion in domestic and foreign markets, as well as some support programmes of research and development, have been initiated. However, the impact of such measures quite limited due to the

* Corresponding author: bond1110@yandex.ru 
constant growth of the tax costs. For example, subsidies to the industries equal to $1 \%$ of its turnover with the total tax burden of about $52 \%$ of its turnover.

According to Russian Federal State Statistics Service (Rosstat), in March 2018, the industrial production index amounted to $101 \%$; $99.8 \%$ in the manufacturing sector, in particular (for comparison, it amounted to $101 \%$ in March 2017) [3]. In the 2000s, the growth rate of industrial production reached $7-8 \%$ overall; and it amounted to more than $10 \%$ for manufacturing enterprises. However, it has not exceeded 5\% [4] since 2012. According to the results of the year 2016, the contribution of manufacturing enterprises to GDP was $13.7 \%$, while it amounted to $9.4 \%$ in the field of mineral extraction; whereas the results of EU countries accounted for $15.9 \%$, that is, the average value for all 28 members, by the percentage of manufacturing enterprises in GDP in 2015, and specifically, this number was equal to $22.8 \%$ in Germany and $27 \%$ in the Czech Republic [5]. Thus, the analysis showed that the growth rates of the industrial production in the Russian economy lagged behind developed economies, provided that they have significantly decreased in recent years.

Rocket and space industry, which once manufactured unique products, also loses its ground. For example, Russia takes the third place, behind the USA and China, by the number of functioning spacecraft. Currently, Russia has a small share in the world space market (it takes about $1 \%$ in the sector of satellite communication and Earth remote sensing and $11 \%$ in the field of rocketand-space equipment production as of 2014) [6].

The analysis of Roscosmos performance over the period of 2015-2016 leads to the conclusion that there are a number of problems in production technology, economy, and human resources, which may result in the violation of its economic sustainability and losses in terms of competitiveness. According to experts, the rocket and space industry is stagnant showing a decline in labor productivity (Table 1).

Table 1. Economic performance of Roscosmos State Corporation.

\begin{tabular}{|c|c|c|c|}
\hline Economic performance & $\begin{array}{c}2015 \\
(\%)\end{array}$ & $\begin{array}{c}2016 \\
(\%)\end{array}$ & Change \\
\hline $\begin{array}{l}\text { Growth of industrial } \\
\text { production }\end{array}$ & 96.6 & 98.0 & +1.4 \\
\hline $\begin{array}{l}\text { Growth of labor } \\
\text { productivity }\end{array}$ & 110.3 & 100.2 & -10.1 \\
\hline
\end{tabular}

Activities planned for the implementation of a government programme entitled «Space activities of the Russian Federation in 2013 - 2020» (hereinafter - State programme) were not implemented fully by Roscosmos State Corporation in 2016 despite the funds that were allocated from the State budget in 2016 and amounted to 210,431.45 million rubles (Table 2) [7].

According to the report, the main causes of a failure to comply with the State programme activities are organizational and managerial factors, a shortage of human resources, and technical factors (an unsuccessful attempt to launch the Progress MS-04 spacecraft due to the 3rd stage engine failure of Soyuz-U rocket. The spacecraft was lost in December 2016).

Table 2. Results of the implementation of the State programme activities by Roscosmos State Corporation in 2016.

\begin{tabular}{|c|c|c|c|}
\hline \multirow{2}{*}{$\begin{array}{l}\text { Parts of the } \\
\text { State } \\
\text { programme }\end{array}$} & \multicolumn{3}{|c|}{$\begin{array}{l}\text { Implementation of State programme } \\
\text { activities in } 2016\end{array}$} \\
\hline & $\begin{array}{c}\text { total } \\
\text { schedule } \\
\text { d number }\end{array}$ & $\begin{array}{l}\text { impleme } \\
\text { nted }\end{array}$ & $\begin{array}{c}\text { not } \\
\text { implemented }\end{array}$ \\
\hline $\begin{array}{l}\text { in terms of } \\
\text { sub- } \\
\text { programme } 1\end{array}$ & 5 & 4 & 1 \\
\hline $\begin{array}{l}\text { in terms of } \\
\text { sub- } \\
\text { programme } 2\end{array}$ & 29 & 19 & 10 \\
\hline $\begin{array}{l}\text { in terms of } \\
\text { Federal } \\
\text { Targeted } \\
\text { Programme } \\
\text { «Federal } \\
\text { Space } \\
\text { Programme - } \\
2025 »\end{array}$ & 115 & 106 & 9 \\
\hline $\begin{array}{l}\text { in terms of } \\
\text { Federal } \\
\text { Targeted } \\
\text { Programme } \\
\text { «Global } \\
\text { Navigation } \\
\text { Satellite } \\
\text { System } \\
\text { (GLONASS)» }\end{array}$ & 50 & 36 & 14 \\
\hline $\begin{array}{l}\text { in terms of } \\
\text { Federal } \\
\text { Targeted } \\
\text { Programme } \\
\text { «Spaceports- } \\
2015 »\end{array}$ & 12 & 3 & 9 \\
\hline $\begin{array}{l}\text { in terms of the } \\
\text { State } \\
\text { programme }\end{array}$ & 211 & 168 & 43 \\
\hline
\end{tabular}

The trend of stagnation in the rocket and space industry is confirmed by the data on the percentage of Russian carrier rocket launches compared to the USA and China figures (Fig. 1). The chart shows a decrease of $43 \%$ in carrier rocket launches compared to 2011.

Figure 2 contains the data on the percentage of Russian spacecraft launched by domestic carrier rockets.

Despite showing not very impressive results, rocket and space industry has gained a solid capacity in order to reach the public policy goals in the space industry.

However, the growing international market for spacebased products and services is influenced by the competition of no less than 40 states actively conducting research and development in the field of innovative space technology and concerned with the issue of their commercial promotion in the consumer market on the most economically favorable terms [9]. In addition, the USA and European countries intensify expensive state 
programmes of development and support of national space corporations. The above-mentioned factors update the task of finding ways to improve the competitive position of Russian space industry.

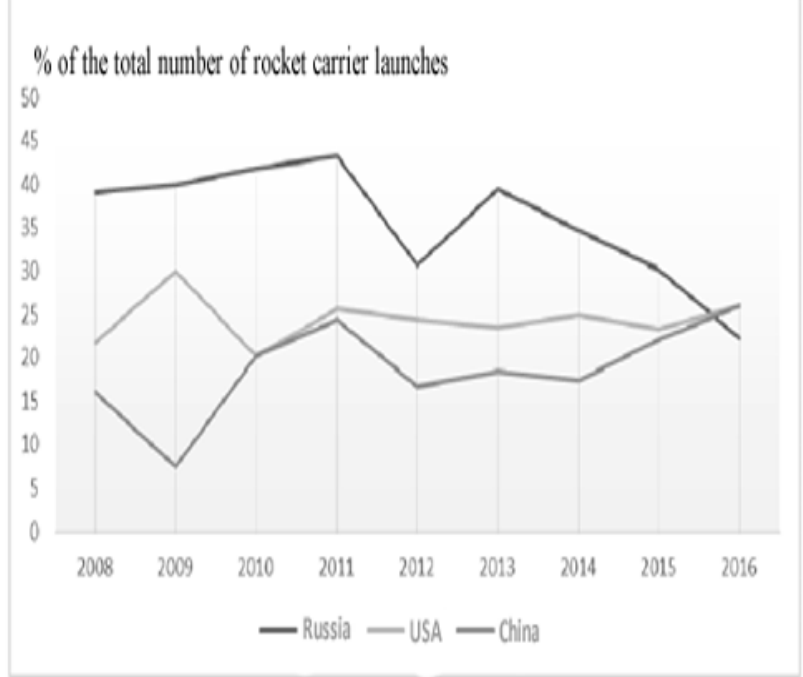

Fig. 1. Evolution of carrier rocket launches on a country-bycountry basis over the 2008 to 2016 period [8].

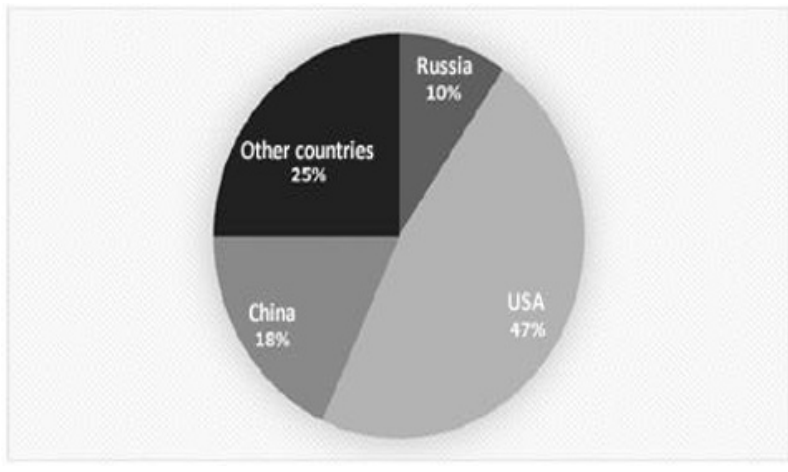

Fig. 2. Percentage of domestic spacecraft launched by Russian carrier rockets in 2016 [8].

The analysis shows that competitors will apparently continue to press Russian producers, which will adversely affect the situation and competitiveness of the aviation and rocket and space domestic industry. The growth of import of essential electronic components shall be able to reduce investments in the development of Russian industrial enterprises in this field, which delays the implementation of new technologies. In our opinion, in order to strengthen the position of domestic industrial enterprises, the following conditions are necessary to be fulfilled: the attraction of additional investments in a large-scale modernization of the production; technological and product innovations corresponding to queries concerning the implementation of strategic projects in priority sectors of the economy; increase in the use of project management technologies at the industrial enterprises in the aviation and rocket and space industry.

In the context of the study, two kinds of competition should be distinguished, namely, overall and strategic. The overall competitiveness of the industry is characterized by the degree of its resource and infrastructure support, access to the financial resources for development, and a variety of the conditions for innovative development, whose implementation can provide the enterprises of the industry with leading positions in the domestic and foreign markets as well as create the conditions for a high quality of production or services provided. A major factor behind the overall competitiveness of the industry is its economic competitiveness, understood as the ability to produce and sell goods (services) meeting the modern requirements of domestic and foreign markets, as well as to create conditions for successful operation and sustainable development of industrial enterprises belonging to the industry [10].

Strategic competitiveness of the industry characterizes its ability to achieve the overall competitiveness in a strategic perspective by implementing all available factors of the innovative development. So, the strategic competitiveness of the rocket and space industry is seen as the set of its essential properties and qualities, which can ensure leading positions of the enterprises belonging to the industry in domestic and foreign markets in the foreseeable future and create such conditions for the owners of enterprises that they could achieve high income and provide decent wages for their workers. In other words, the strategic competitiveness of an enterprise can be considered as its potential ability to compete in the specific markets in the future, which is provided by an increase in manifestations of strategic exclusive competitive advantages.

It is possible to ensure the achievement of strategic competitiveness of the industry on the basis of specific competitive strategies providing a gradual movement of the enterprises of the industry to an innovative model of development through creating necessary conditions. A strategy can be defined as a set of goals and methods to achieve them, which shall be constantly adjusted in terms of a dynamic volatile external environment in order to adapt the enterprises to the changes of the environment during the process of achievement strategic guidance. Let us consider two possible competitive strategies.

Clustering strategy is based on the methodology of cluster analysis that allows identifying territorial, institutional, informational, and innovative background of competitive advantages of particular industry development. In the literature, a cluster is most often defined as a set of an interrelated group of successful companies, which form the «golden ratio» of the economic system of a specific territory and provide competitive positions in industrial, national, and global markets. The development of a cluster leads to the formation of additional benefits at the expense of the introduction of new intrinsic cluster properties. The competitiveness of a particular territory (region) is grounded on strong positions of individual clusters and greatly dependent on the level of their development.

Capitalization strategy of leading economic sectors means that the main strategic economic sectors, which provide the competitive advantages of Russia in the world market, shall be primarily subject to capitalization. 
The analysis shows that so far export commodity sector, trade, and infrastructure industries are the main competitive sectors of the Russian economy. However, the industrial sector of the economy experiences difficulties with the access to financial resources.

A well-known thesis by Joseph Schumpeter stating that «an innovator rides to success on their debts» does not operate in Russian environment. Russian banks provide credits to enterprises depending on the gross margin, the consistency of monthly turnover, and under the conditions of the secondary pledge, namely, collateral. However, it is the innovative enterprises that are not able to meet none of the above-mentioned conditions. Banks seek to minimize risks and maintain the high profitability of their transactions, which does not appeal to the real sector of economy. This situation indicates that there is a serious «structural paradox» in Russian economy and that the government does not operate effectively in the innovative and industrial fields. For this reason, one shall not expect breakthroughs in the innovative field without developing and implementing a science-based strategy for the innovative development of Russia in the long term.

It should also be noted that different enterprises and industries have different strategic competitiveness, and therefore there cannot be a common competitive strategy of development for all sectors of the Russian economy, as well as there is no a common strategy of project management aimed at solving various issues, which are associated with dynamism and volatility of the internal and external environment.

The use of project management tools at the industrial enterprises in the aviation and rocket and space industry is related to the need to address such challenges as a failure to meet a date of project implementation, large volumes of work in process, the variability of processes of implementation plans, increase in funding, and deficiencies in the management of supply and resource flows. The introduction of project management tools in the operation of space industry enterprises will make it possible to respond to existing shortcomings related to the opacity of ongoing processes at the enterprises and their associated financial and time losses. The integration of enterprises within Roscosmos State Corporation without implementing the most advanced management methods and systems and without a fundamental change in business process shall not lead to such a level of changes, which is necessary for the industry in order to remain competitive in foreign markets. The analysis shows that there is a current problem of resistance to the concept of project management, which leads to failures to meet dates of government orders and helplessness of the management in the face of arising internal and external challenges. Moreover, there is a loss of time and knowledge connected with the development of new equipment and technologies. The problems are significant obstacles to the innovation development of the enterprises; their removal lays in the review of approaches to the management of functioning and development of the enterprises belonging to the aviation and rocket and space complexes. A progressive implementation of the advanced project management mechanisms and tools for the innovation development of industrial enterprises included in these complexes is necessary.

In our opinion, the implementation of project management tools at the aviation and rocket and space industry enterprises will make it possible to improve the use of all resources of the country, as well as to manufacture sophisticated knowledge-intensive products (devices, appliances) on a new technological basis. The practice of management shows that the introduction of project management methods and tools saves up to $20 \%$ of funds and $30 \%$ of time during the implementation of projects and programmes [11]. Taking into account the specificity of the aircraft and rocket and space complexes, project management is a real alternative to the existing management practice. The benefits of the project management of innovation activities at the enterprises of aviation and rocket and space complexes are the following: a decline in a number of all kinds of failures during the implementation of projects and state programmes; reduction in the time necessary for the implementation of strategically important projects; reduction in total cost of projects; saving all kind of resources; an ability to evaluate the performance of investments in a specific project; and a possibility to quickly analyse all business processes of a specific project with a view to optimizing them.

Thus, conducting innovation transformations and developing the competitive potential of Russian industrial enterprises shall be based on the introduction of the latest technologies, improvement of business environment, and the use of modern project management tools. The innovation development of the enterprises belonging to the aviation and rocket and space complexes based on project management requires many resources but the foreign experience has shown that the expenses are paid off manifold in the long term. The result-oriented use of project management methods and tools, improving business processes and creating an institutional environment for investment in the industry and new technologies should raise Russian industrial enterprises to a qualitatively new level of operation and development, as well as develop their competitive potential.

\section{References}

1. Bank of Russia, URL: http://cbr.ru (date of access: 05.05.2018).

2. On the status of the competitiveness of Russian enterprises, URL: http://meforum.ru/media/news/8543/ (date of access: 03.04.2018).

3. Federal State Statistics Service, URL: http://www.gks.ru/ (date of access: 28.03.2018

4. V. S. Osmakov, A. M. Kalinin Issues of Economics 5, 45-59, (2017)

5. Eurostat, URL: http://ec.europa.eu/eurostat (date of access: 28.03.2018). 
6. Roscosmos State Corporation estimated Russia's in the world space market // GLONASS Bulletin. (2016), January 26, URL: http://vestnikglonass.ru/news/tech/roskosmosotsenil-dolyu-rossiina-mirovom-kosmicheskom-rynke/ (date of access: 05.02.2018).

7. Roscosmos State Corporation official website, URL: http://www.rusnano.com/about/structure http://www.roscosmos.ru/219/ (date of access: 20.03.2018).

8. A.S. Slavyanov, O.E. Khrustalyov. Polythematic web electronic academic periodical of Kuban State Agrarian University 128, 1116-1130, (2017)

9. Euroconsult. URL: http:// www.euroconsult-ec.com (date of access: 03.04. 2018).

10. M.A. Afonasova. The Social Science 9, 2206-2212, (2015)

11. V.A. Gafiatullin. University Bulletin 3, 165-170, (2016) 